Article

\title{
Leptin Downregulates Angulin-1 in Active Crohn's Disease via STAT3
}

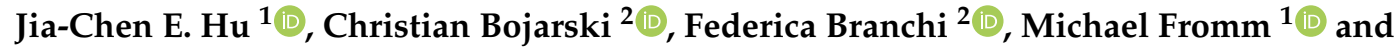 \\ Susanne M. Krug 1,*(D) \\ 1 Institute of Clinical Physiology/Nutritional Medicine, Charité-Universitätsmedizin Berlin, \\ Campus Benjamin Franklin, 12203 Berlin, Germany \\ 2 Department of Gastroenterology, Rheumatology and Infectious Diseases, Charité-Universitätsmedizin \\ Berlin, Campus Benjamin Franklin, 12203 Berlin, Germany \\ * Correspondence: susanne.m.krug@charite.de
}

Received: 2 October 2020; Accepted: 20 October 2020; Published: 22 October 2020

\begin{abstract}
Crohn's disease (CD) has an altered intestinal barrier function, yet the underlying mechanisms remain to be disclosed. The tricellular tight junction protein tricellulin is involved in the maintenance of the paracellular macromolecule barrier and features an unchanged expression level in CD but a shifted localization. As angulins are known to regulate the localization of tricellulin, we hypothesized the involvement of angulins in CD. Using human biopsies, we found angulin-1 was downregulated in active CD compared with both controls and CD in remission. In T84 and Caco-2 monolayers, leptin, a cytokine secreted by fat tissue and affected in CD, decreased angulin-1 expression. This effect was completely blocked by STAT3 inhibitors, Stattic and WP1066, but only partially by JAK2 inhibitor AG490. The effect of leptin was also seen at a functional level as we observed in Caco-2 cells an increased permeability for FITC-dextran $4 \mathrm{kDa}$ indicating an impaired barrier against macromolecule uptake. In conclusion, we were able to show that in active CD angulin-1 expression is downregulated, which leads to increased macromolecule permeability and is inducible by leptin via STAT3. This suggests that angulin- 1 and leptin secretion are potential targets for intervention in $\mathrm{CD}$ to restore the impaired intestinal barrier.
\end{abstract}

Keywords: leptin; Crohn's disease; tight junction; angulin-1

\section{Introduction}

Crohn's disease $(C D)$ is a chronic idiopathic relapsing and remitting gastrointestinal condition with a climbing prevalence in western countries and an increasing incidence in developing regions [1,2]. Besides genetic predisposition, environmental influence and microbiota, the pathogenesis of CD might also result from miscommunication between intestinal epithelial cells and the immune system [3]. Cytokines play a compelling role in balancing immune function, but also could exert pathological effects on the immune system when excessively produced. Leptin is a special kind of cytokine secreted largely by adipose tissue. Hypertrophic and hyperplastic adipocytes could lead to cell apoptosis, hypoxia, macrophages infiltration, and proinflammatory cytokines releasement (i.e., TNF- $\alpha$, IL-1 $\beta$ and IL-6) [4]. In CD, a characteristic thickened mesenteric fat tissue adjacent to inflamed intestinal segments was described [5]. This "creeping fat" could be an important source of additional cytokine release. Under inflammatory conditions, an increasing amount of leptin could lead to the damage of the epithelial wall and the infiltration of neutrophils [6-8].

The tight junction (TJ) acts as a critical part in maintaining the intactness of the intestinal barrier and is considered a determinant of the paracellular transport. On one hand, it behaves as a "fence" that prevents movement of membrane constituents between apical and basolateral cell membranes [9]. 
On the other hand, the TJ has a "gate function" that controls the passage of water, ions, small water-soluble molecules, and macromolecules through the intercellular space [10]. The structure of the TJ comprises two patterns, the bicellular TJ (bTJ) formed by a belt-like meshwork of strands between two epithelial cells [11] and the tricellular TJ (tTJ) which is situated in the region where three cells meet and consists of vertically extended bTJs, forming a central tube [12]. Due to the space left in the central tube, the tTJ is assumed to be a weak region for the total paracellular barrier and by this a potential route for transepithelial fluxes. Tricellulin and the angulin family are the major protein components of $\mathrm{tTJ}$. Tricellulin is essential for maintaining an intact $\mathrm{tTJ}$ assembly as well as its barrier function, especially that for macromolecules $[13,14]$.

Why this is essential deserves some explanation. Under normal conditions, the intestinal epithelial barrier prevents significant uptake of luminal antigens into the lamina propria. However, if the $\mathrm{tTJ}$ barrier is opened for the passage of large molecules, luminal antigens can enter the lamina propria. There, they stimulate local immune cells to develop a proinflammatory response by releasing chemokines which exacerbate the intestinal inflammatory process in $\mathrm{CD}[3,15]$.

The angulin family comprises three members featuring a common ability to recruit tricellulin to the tTJ [16]. Angulin-1, also named lipolysis-stimulated lipoprotein receptor (LSR), was initially recognized as a rate-limiting step in the progress of lipid clearance [17] and later identified to have a primary localization at the tTJ [18]. Angulin-1 could recruit tricellulin to the tTJ, and knockdown of angulin-1 leads to a decreased transepithelial resistance (TER) and an increased permeability to fluorescein and macromolecules up to $40 \mathrm{kDa}$ [18], indicating that angulin-1—probably indirectly acting by the removal of tricellulin from the tTJ-was also essential for sustaining the epithelial barrier. To date, angulin-1 has been linked to lipid metabolic abnormality [19-21], Alzheimer's disease [22], and various cancers [23-30]. Akin to tricellulin, angulin-1 is also targeted by bacteria in order to breach the intestinal barrier [31,32]. In vitro cell culture experiments also showed leptin downregulating angulin-1 at pathological concentrations [27,33]. In all epithelia with the expression of tricellulin, at least one angulin localizes at the tTJ and in colon the major role falls on angulin-1 [16].

Dysregulation of TJ proteins could cause or could be caused by corresponding diseases due to altered paracellular passage of water, solutes, and macromolecules [34]. In CD, TJs are altered in ultrastructure as well as protein expression and localization [35]. Expression of tricellulin was found to be shifted from depths of crypts to surface epithelium in $C D$ while its expression was unaltered [15]. Although the regulatory mechanisms behind this shifting and the underlying components are unexplored, a reasonable hypothesis would be that the displacement of tricellulin might result from elements responsible for its correct localization.

In this study, we focused on analyzing the expression of $\mathrm{tTJ}$ proteins in $\mathrm{CD}$ and found angulin-1 to be downregulated. Then, we also aimed to discover the affecting factors behind this and found out that leptin was able to cause the expressional alteration of angulin- 1 and that the involved mediator was STAT3.

\section{Results}

\subsection{Patients Features}

In total, $19 \mathrm{CD}$ patients and 24 patients without intestinal diseases who underwent colonoscopy were enrolled for the study between 2017 and 2020 (Table 1). Simple endoscopic score for CD (SES-CD) is a simplified scoring system that is commonly used to evaluate the endoscopic presentation of CD patients, the items of which includes mucosal ulcers, surface involved by $\mathrm{CD}$ or ulceration, and the presence of narrowing [36]. 
Table 1. Characteristics of the enrolled Crohn's disease (CD) population.

\begin{tabular}{ccc}
\hline Characteristic & Controls $(n=24)$ & CD $(n=19)$ \\
\hline Age (median, range) & $54(24-66)$ & $35(25-64)$ \\
Gender (male/female) & $8 / 16$ & $5 / 14$ \\
SES-CD, $n$ & - & 5 \\
Remission $(0-2)$ & - & 14 \\
Active $(>2)$ & & \\
\hline
\end{tabular}

\subsection{Expression of Angulins in Intestinal Biopsies}

Regarding mRNA levels, angulin-1 showed a downregulation in active CD compared with healthy controls (Figure 1a, ${ }^{*} p<0.05$,) and a recovered expression in remission CD compared with CD-active patients (Figure $1 \mathrm{a},{ }^{*} p<0.05$,). Despite not being significant, the similar pattern could be found in angulin-2 expression (Figure 1b). The expression of angulin-3 remained unchanged in CD (Figure 1c). As controls, expression of claudin-2, -4 and tricellulin were checked. Claudin-2 (Cldn-2) was upregulated as already known in active CD compared to healthy controls (Figure 1 e, ${ }^{* *} p<0.01$,) as well as to $\mathrm{CD}$ in remission (Figure $1 \mathrm{e},{ }^{*} p<0.05$ ). The expression of tricellulin and claudin-4 (Cldn-4) remained unchanged in CD (Figure 1d,f).

\section{Angulin-1}

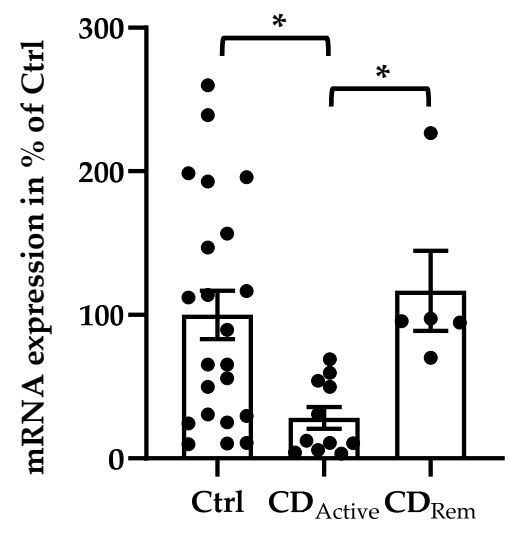

(a)

Angulin-3

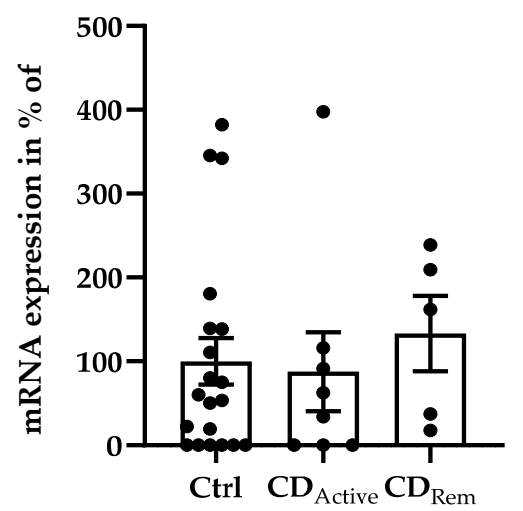

(c)
Angulin-2

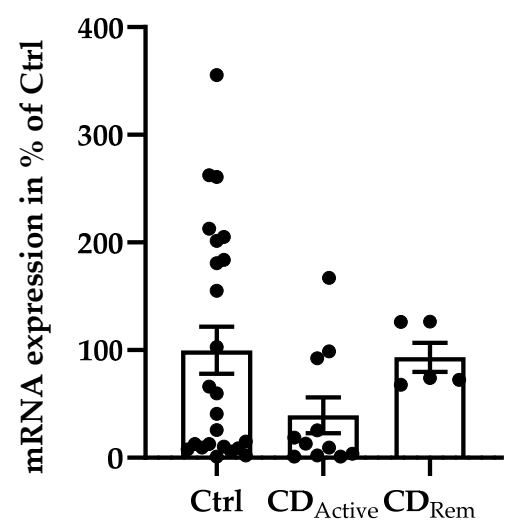

(b)

Tricellulin

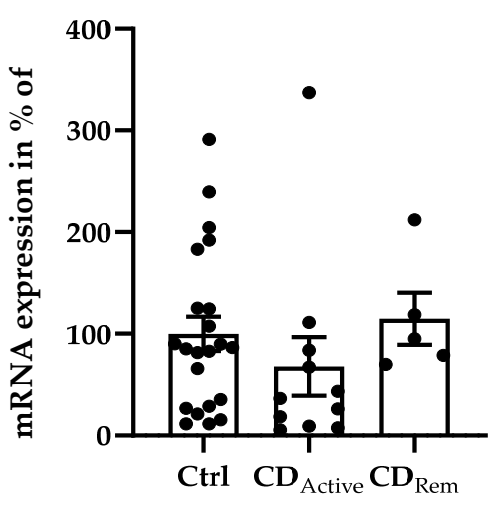

(d)

Figure 1. Cont. 
Cldn-2

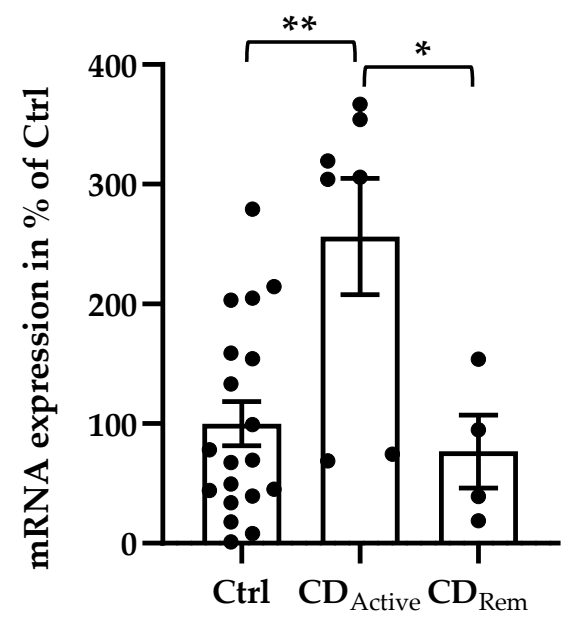

(e)
Cldn-4

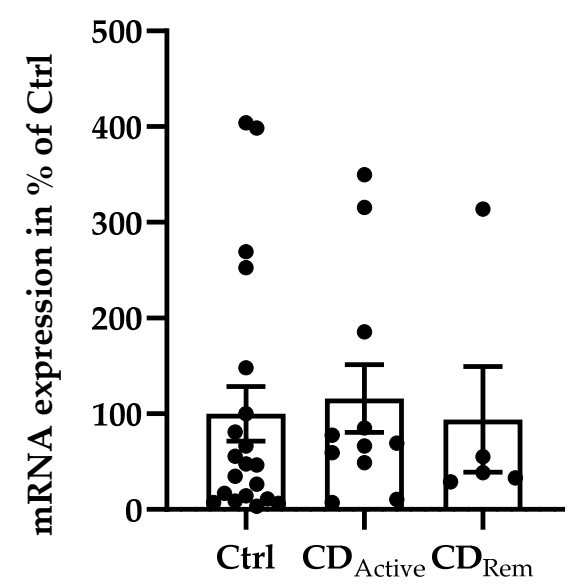

(f)

Figure 1. Scatter and bar plots of tight junction (TJ) protein mRNA expression analysis of human intestinal tissue. Mean value of controls (Ctrl) is set to $100 \%$. (a) Angulin-1 is downregulated in active CD $(28.26 \pm 7.62 \%, n=11)$ compared to Ctrl $(100 \pm 16.81 \%, n=22, * p<0.05)$ and remission patients $(116.86 \pm 27.87 \%, n=5, * p<0.05)$. (b) Angulin-2: Ctrl $=100 \pm 21.85 \%$, $\left.n=24 ; \mathrm{CD}_{\text {Active }}=37.63 \pm 16.14 \%, n=11 ; \mathrm{CD}_{\text {Rem }}=97.44 \pm 12.52 \%, n=5\right)$. (c) Angulin-3: Ctrl $=100 \pm 27.54 \%, n=20 ; \mathrm{CD}_{\text {Active }}=87.78 \pm 46.96 \%, n=8 ; \mathrm{CD}_{\text {Rem }}=133.09 \pm 44.91 \%, n=5$. (d) Tricellulin: $\mathrm{Ctrl}=100 \pm 16.75 \%, n=22 ; \mathrm{CD}_{\text {Active }}=67.87 \pm 28.82 \%, n=11 ; \mathrm{CD}_{\mathrm{Rem}}=114.90 \pm 25.69 \%$, $n=5$. (e) Cldn-2 shows an increase in CDActive $(256.28 \pm 48.51 \%, n=7)$ in comparison with Ctrl $\left(100 \pm 18.61 \%, n=19,{ }^{* *} p<0.01\right)$ and remission $\mathrm{CD}\left(76.67 \pm 30.36 \%, n=4{ }^{*} p<0.05\right)$. (f) Cldn- 4 : Ctrl $=100 \pm 28.64 \%, n=20 ; \mathrm{CD}_{\text {Active }}=127.67 \pm 39.31 \%, n=11 ; \mathrm{CD}_{\text {Rem }}=68.33 \pm 29.68 \%, n=5$.

Regarding protein expression levels, angulin-1 in formalin-fixed paraffin-embedded (FFPE) intestinal biopsies was decreased in CD when compared to healthy controls (Figure $2 \mathrm{a}, \mathrm{b},{ }^{*} p<0.05$ ). Since epithelial cells may not be homogeneously distributed within each paraffin-embedded section, the protein expression from freshly taken biopsies was then also analyzed to avoid sample selection bias. Protein extracted from the whole colonic biopsy which did not undergo the fixation or embedding procedure confirmed a reduced expression of angulin-1 in active CD compared with Ctrl as well as remission CD (Figure $2 \mathrm{c}, \mathrm{d},{ }^{* *} p<0.01$ ). As controls, we also analyzed the protein expression of tricellulin and Cldn-4 and found them to be unaltered as previously demonstrated [15] (Figure S1).

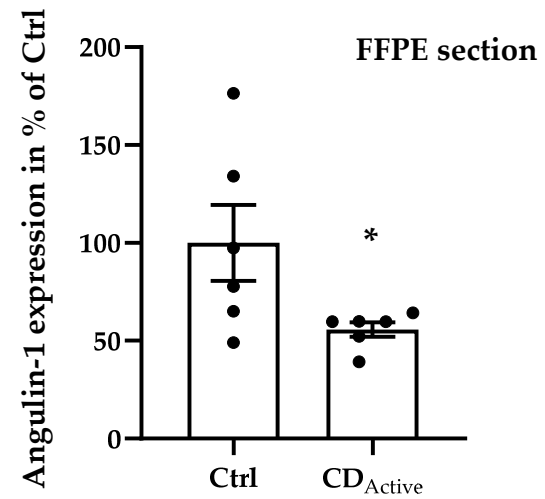

(a)

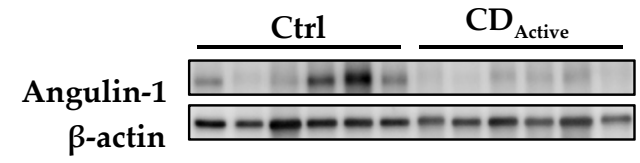

(b)

Figure 2. Cont. 


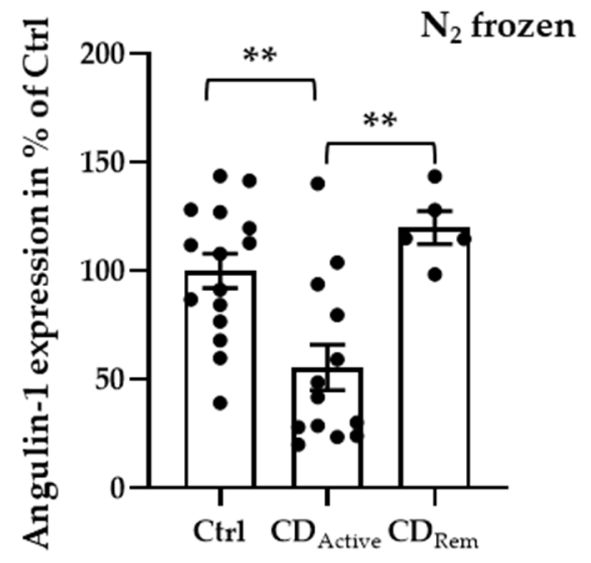

(c)

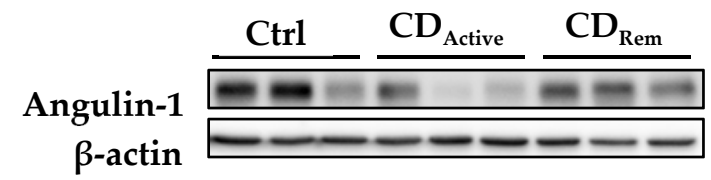

(d)

Figure 2. Angulin-1 protein expression analysis of human intestinal tissues. (a) Scatterplot with bar of angulin-1 in formalin-fixed paraffin-embedded (FFPE) section of Ctrl and CD. Mean value of Ctrl is set to 100\%. Angulin-1 is downregulated in CD (Ctrl: $100 \pm 19.42 \%, n=6$; CD: $55.82 \pm 3.67 \%, n=6$, * $p<0.05$ ). (b) Representative Western blots of intestinal tissues of Ctrl and CD. (c) Scatterplot with bar of angulin-1 in biopsies directly frozen after colonoscopy from Ctrl, active CD, and remission CD. Mean value of $\mathrm{Ctrl}$ is set to $100 \%$. Angulin-1 is downregulated in active $\mathrm{CD}\left(\mathrm{CD}_{\text {Active }}: 55.59 \pm 10.50 \%, n=13\right)$ compared with Ctrl (Ctrl: $\left.100 \pm 7.95 \%, n=15,{ }^{* *} p<0.01\right)$ and remission CD ( $\mathrm{CD}_{\text {Rem }}: 120.00 \pm 7.54 \%$, $\left.n=5,{ }^{* *} p<0.01\right)$. (d) Representative Western blots of intestinal tissues of Ctrl and CD.

\subsection{Cytokine Effects of Angulins in Human Intestinal Epithelial Cell Lines}

In order to figure out the potential responsible cytokines of the downregulated angulin- 1 in $C D$, intestinal epithelial cell lines T84 and Caco-2 were cultured for the treatment of twelve cytokines which were reported in the literature to possess proinflammatory effects (TNF- $\alpha$, IFN- $\gamma$, leptin, IL- $1 \beta$, IL-6, IL-12, IL-17A, IL-17F, IL-21, IL-22, IL-23 and IL-33).

For T84 cells, leptin was the only cytokine that downregulated angulin- 1 (to $81.11 \pm 2.07 \%$ of untreated Ctrl after $48 \mathrm{~h}$ ), while all the other cytokines investigated showed no effect (Figure S2, ${ }^{* * *} p<0.001, n=12$ ). There was no change of TER after leptin treatment (Figure S3c).

For Caco-2 cells, angulin-1 protein expression was also only decreased by leptin to $82.38 \pm 1.03 \%$ (Figure S4c, ${ }^{* * *} p<0.001, n=12$ ) and was increased by TNF- $\alpha$ or IL-17F (Figure S4a, ${ }^{* *} p<0.01, n=12$; Figure S4h, ${ }^{*} p<0.05, n=9$ ). The TER value also did not change after leptin treatment (Figure S5c).

To further explore the effect of leptin, T84 and Caco-2 cells were incubated for different periods (24, 48, and $96 \mathrm{~h}$ ) to compare the protein expression course of angulin- 1 and tricellulin. In T84 cells, compared to the effect at $48 \mathrm{~h}$ described above, angulin-1 protein expression after $96 \mathrm{~h}$ of leptin treatment was further reduced to $58.66 \pm 2.62 \%$ of untreated Ctrl (Figure $3 a,{ }^{* * *} p<0.001$ ). Tricellulin protein expression was stable at all three time points (Figure $3 b$ ).

In Caco-2 cells, the results were similar: angulin-1 protein expression after $96 \mathrm{~h}$ of leptin treatment was downregulated to $67.71 \pm 1.68 \%$ compared to $24 \mathrm{~h}$ (Figure $4 \mathrm{a}$, ${ }^{* * *} p<0.001, n=6$ ) as well as $48 \mathrm{~h}$ (Figure $4 \mathrm{a},{ }^{* * *} p<0.001, n=12$ ), and the expression level of angulin- 1 at $48 \mathrm{~h}$ was also lower than at $24 \mathrm{~h}$ (Figure $4 \mathrm{a},{ }^{* * *} p<0.001$ ). Additionally, in Caco-2 cells there was no difference in tricellulin expression at all time points tested (Figure $4 b$ ). 


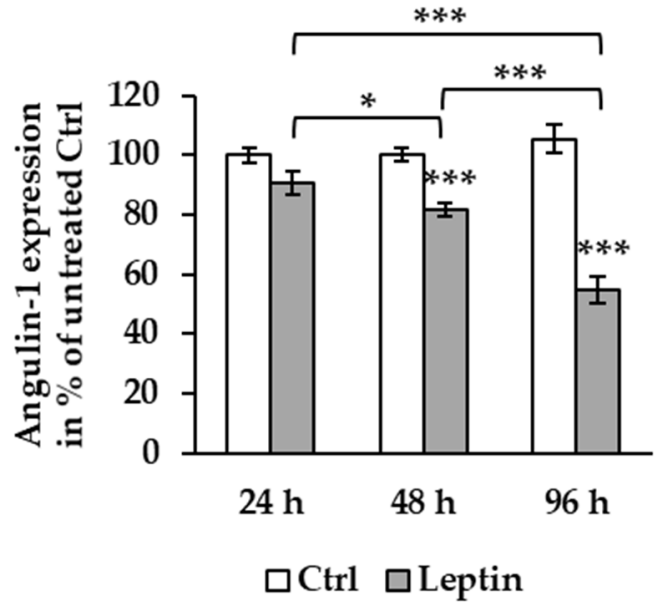

(a)

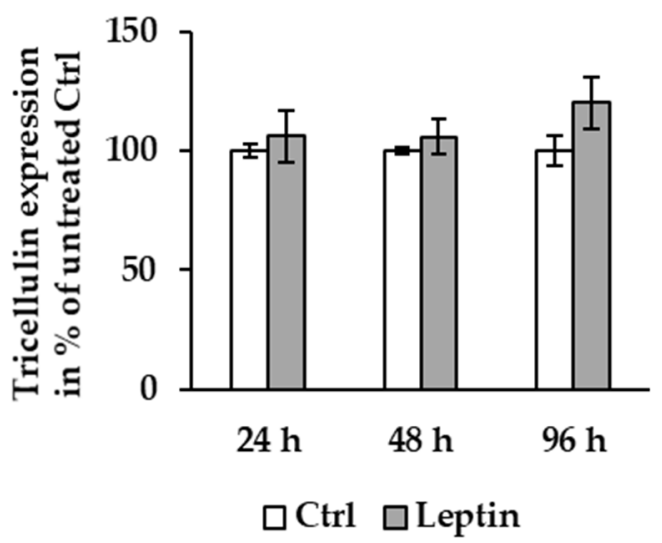

(b)

Figure 3. Protein expression effect of leptin at different time points in T84 cells. (a) Densitometric analysis shows angulin- 1 expression to be $90.68 \pm 3.83 \%$ at $24 \mathrm{~h}(n=6), 81.11 \pm 2.07 \%$ at $48 \mathrm{~h}\left({ }^{* * *} p<0.001\right.$, $n=12)$, and $58.66 \pm 2.62 \%$ at $96 \mathrm{~h}\left({ }^{* * *} p<0.001, n=12\right)$ compared to untreated Ctrl. The protein expression at $96 \mathrm{~h}$ is decreased compared to both 24 (** $\left.^{* *}<0.001\right)$ and $48 \mathrm{~h}\left({ }^{* * *} p<0.001\right)$. At $48 \mathrm{~h}$, angulin-1 expression is also lower than $24 \mathrm{~h}\left({ }^{*} p<0.05\right)$. (b) Tricellulin expression level shows no differences between $24(n=6), 48(n=12)$, and $96 \mathrm{~h}(n=12)$.

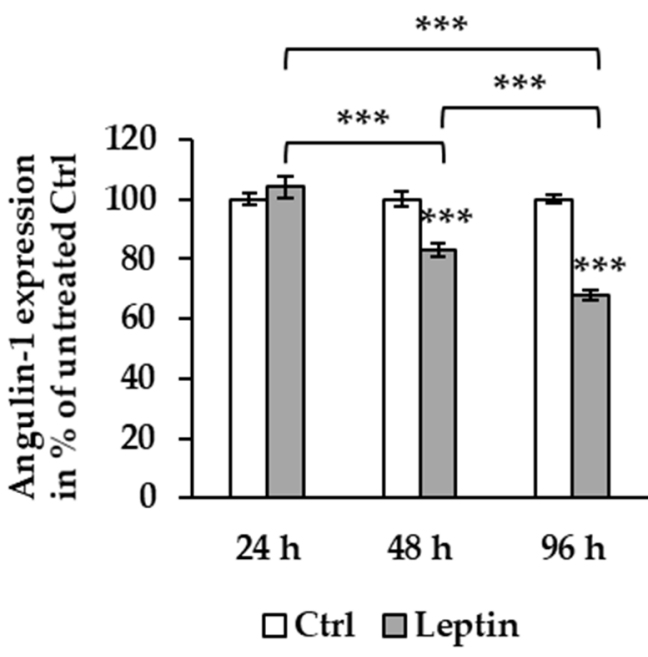

(a)

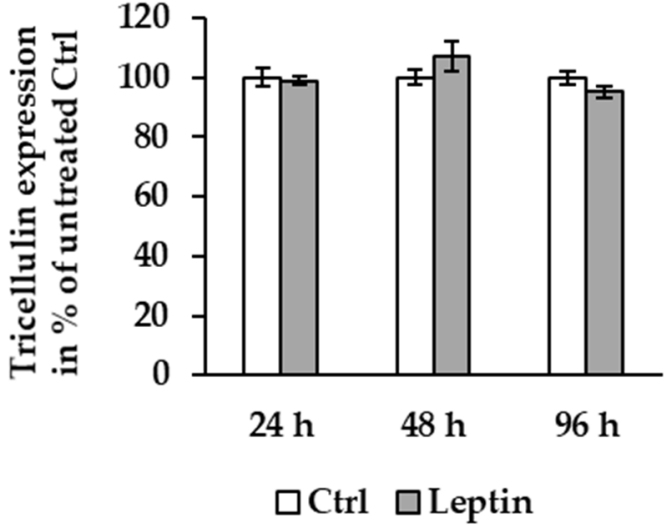

(b)

Figure 4. Effect of leptin on protein expression at different time points in Caco-2 cells. (a) Angulin-1 expression level exhibits reduction at $48\left(82.38 \pm 1.03 \%\right.$, $\left.{ }^{* * *} p<0.001, n=12\right)$ and $96 \mathrm{~h}(67.71 \pm 1.68 \%$, *** $p<0.001, n=12)$ of leptin treatment compared to untreated Ctrl. There is a significant difference between 24 and $48 \mathrm{~h}\left({ }^{* * *} p<0.001\right), 48\left(^{* * *} p<0.001\right)$ and $96 \mathrm{~h}\left({ }^{* * *} p<0.001\right)$, and 24 and $96 \mathrm{~h}$.

(b) Tricellulin expression is not affected by leptin at 24,48 , or $96 \mathrm{~h}$.

\subsection{Barrier Function of T84 and Caco-2 Cells Treated with Leptin}

To explore whether the downregulation of angulin- 1 by leptin could affect the macromolecule barrier function, permeability for the macromolecule marker FITC-dextran $4 \mathrm{kDa}$ (FD4) was measured in T84 and Caco-2 cells after leptin treatment. TER values were not different with or without leptin 
treatment in both cell lines (Figure 5a,c). Regarding FD4 permeability, no significant change was observed in T84 cells (Figure 5b), but values in Caco-2 cells nearly doubled (Figure $5 d,{ }^{*} p<0.05$ ).

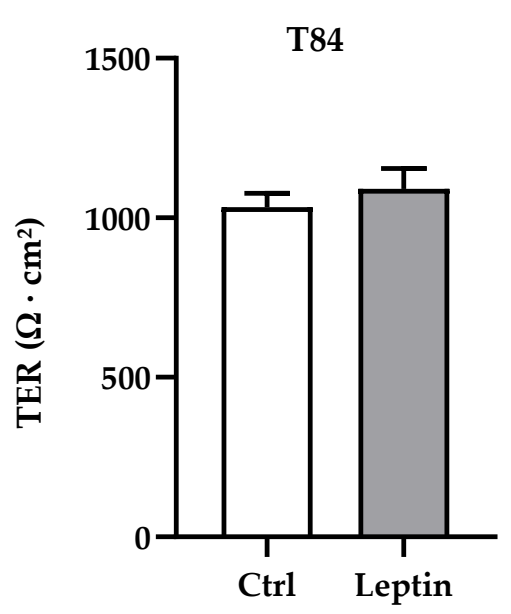

(a)

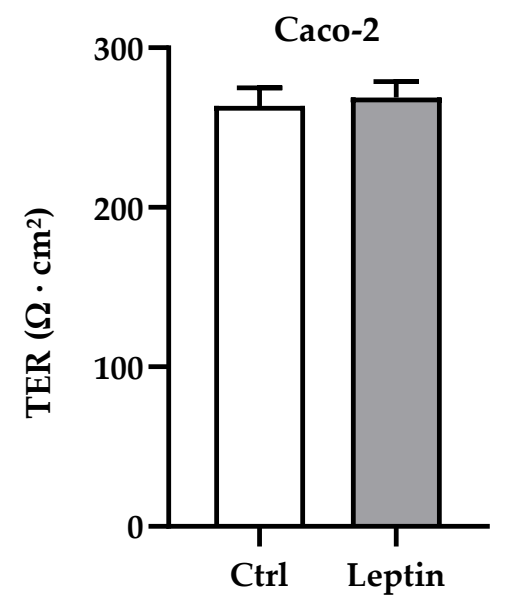

(c)

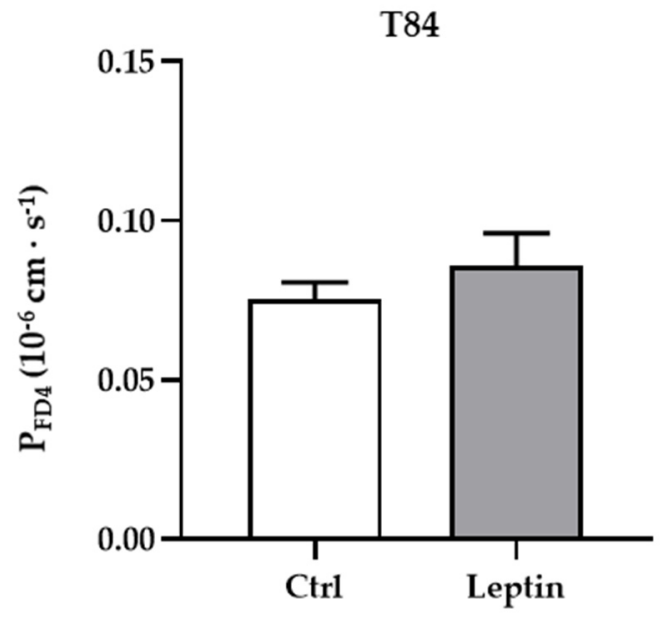

(b)

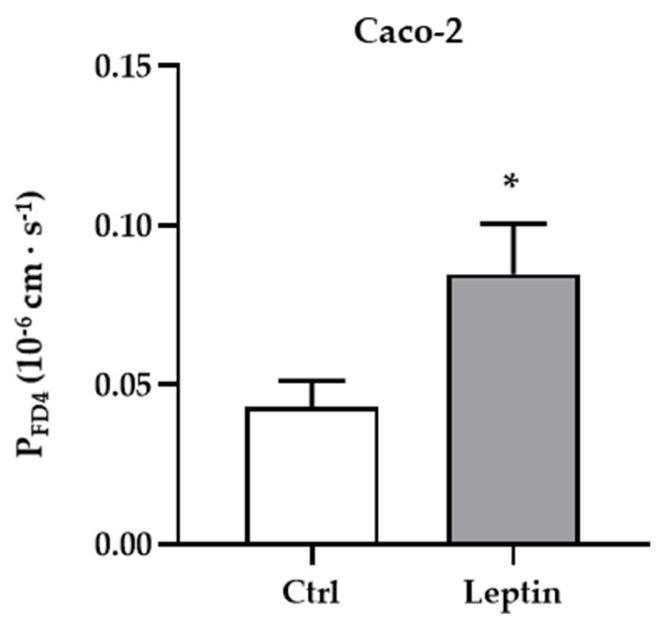

(d)

Figure 5. Functional analysis in T84 and Caco-2 cells. (a) Transepithelial resistance (TER) in T84 cells. (b) Permeability for FITC-dextran $4 \mathrm{kDa}\left(\mathrm{P}_{\mathrm{FD} 4}\right)$ in T84 cells: $\mathrm{Ctrl}=0.075 \pm 0.005 \times 10^{-6} \mathrm{~cm} \cdot \mathrm{s}^{-1}$, $n=9$; leptin $=0.086 \pm 0.010 \times 10^{-6} \mathrm{~cm} \cdot \mathrm{s}^{-1}, n=8$. (c) Transepithelial resistance in T84 cells. (d) Permeability for FITC-dextran $4 \mathrm{kDa}$ in Caco-2 cells: Ctrl $=0.045 \pm 0.008 \times 10^{-6} \mathrm{~cm} \cdot \mathrm{s}^{-1}, n=9$; leptin $=0.083 \pm 0.016 \times 10^{-6} \mathrm{~cm} \cdot \mathrm{s}^{-1}, n=11, * p<0.05$.

\subsection{Tricellulin Localization after Leptin Treatment}

To determine whether the treatment with leptin could lead to a spatial shift of tricellulin, we performed immunofluorescent staining to exhibit the localization. Tricellulin was not affected by leptin treatment as its localization at tTJs remained unchanged (Figure 6). 


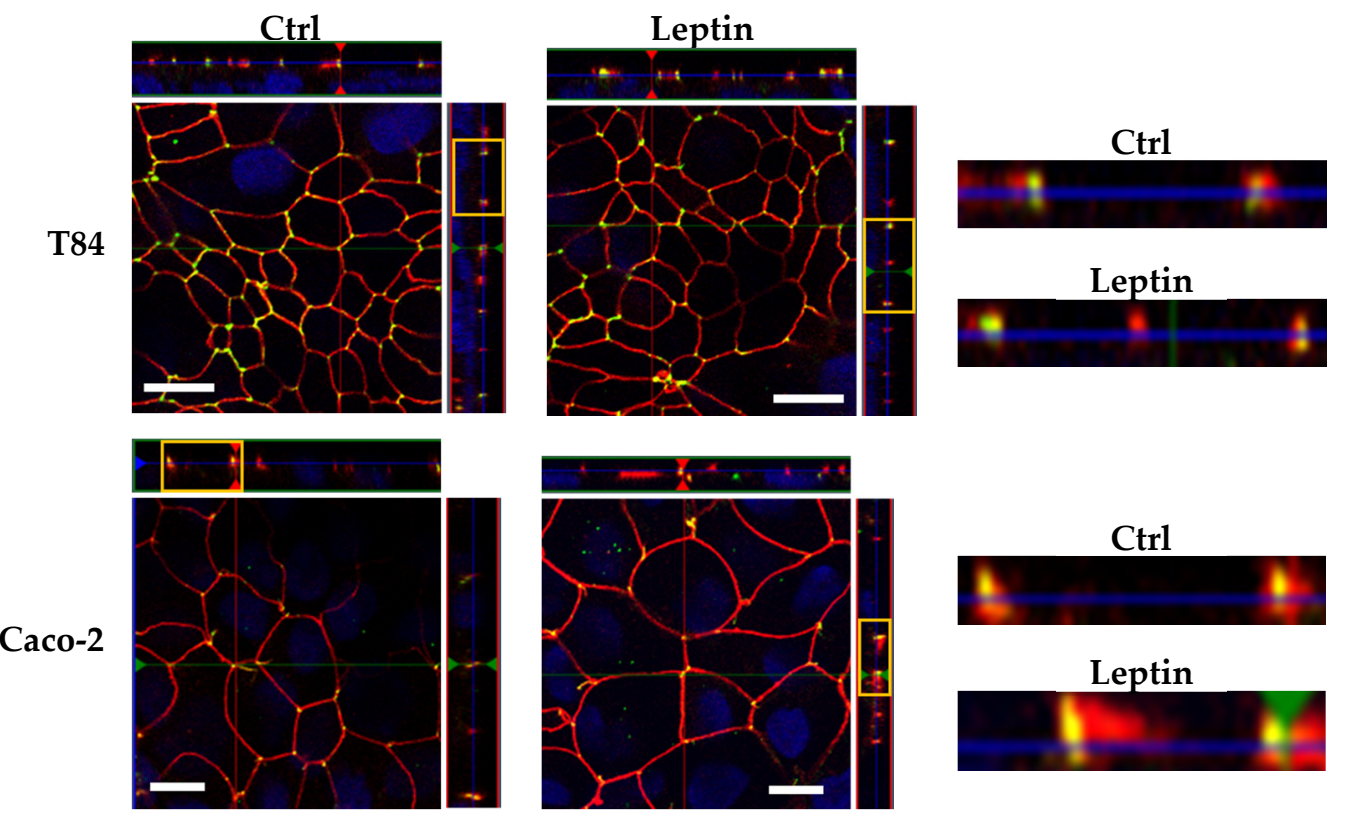

Figure 6. Representative immunofluorescent staining of tricellulin (green) and ZO-1 (red) in human intestinal cell lines. Nuclei were stained using 4',6-diamidino-2-phenylindole (DAPI) (blue). With the TJ indicator ZO-1, the localization of tricellulin at tricellular TJ (tTJs) are demonstrated. The selected Z-scans (yellow box) are magnified on the right, indicating that there were no localization shifts in the lateral direction. Bars $=10 \mu \mathrm{m}$.

\subsection{Signaling Pathway of Leptin}

To investigate the signal transduction of leptin-induced angulin-1 downregulation, several inhibitors of known signaling pathways (e.g., JAK2 [37], STAT3 [27], ERK1/2 [38], and PI3K [39]) of leptin were added before treatment. STAT3 inhibitors, Stattic as well as WP1066, were able to block the effect of leptin in both T84 (Figure 7a, ${ }^{* * *} p<0.001, n=6$ ) and Caco-2 cells (Figure 7b, ${ }^{* * *} p<0.001$, $n=6$ ), while in both cell lines this effect could only be partially inhibited after the blockage of the assumed upstreaming JAK2 pathway (Figure $7 \mathrm{a}, \mathrm{b},{ }^{*} p<0.05, n=6$ ).

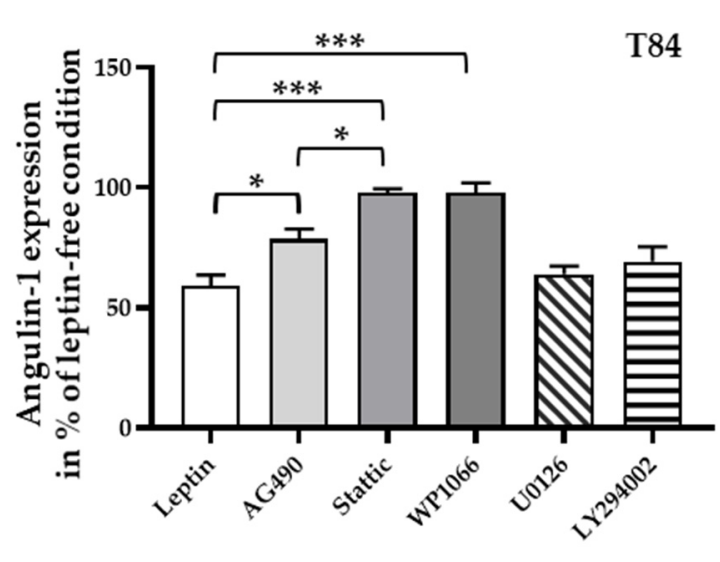

(a)

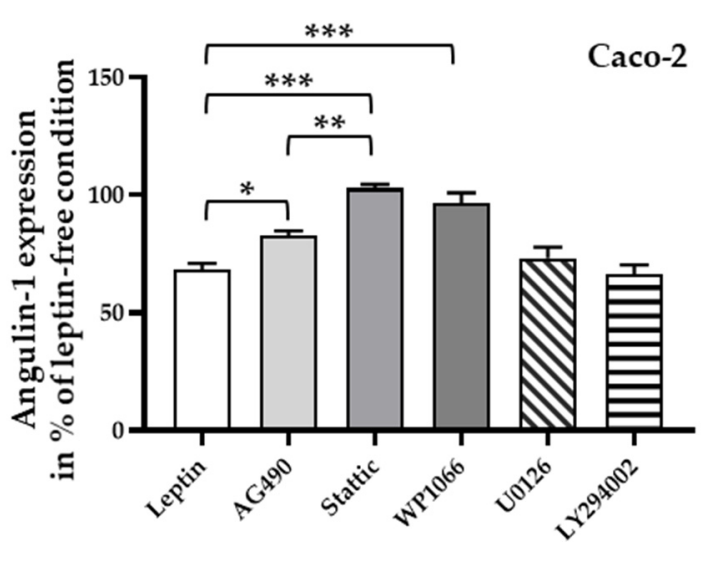

(b)

Figure 7. Densitometric analysis of angulin-1 expression after incubation with leptin and pre-treated with different inhibitors in T84 cells (a) and in Caco-2 cells (b). ${ }^{*} p<0.05,{ }^{* *} p<0.01,{ }^{* * *} p<0.001, n=6$.

To further elucidate the regulation of STAT3, a phosphorylation protein analysis was carried out and showed an increase in phosphorylation, becoming significant after $30 \mathrm{~min}$ (T84 cells, Figure 8a, 
${ }^{* *} p<0.01, n=7$; Caco-2 cells, Figure $8 \mathbf{b},{ }^{*} p<0.05, n=6$ ) and reaching a peak at 60 min after leptin treatment (T84 cells, Figure 8a, ${ }^{* *} p<0.001, n=11$; Caco-2 cells, Figure 8b, ${ }^{* * *} p<0.001, n=9$ ).

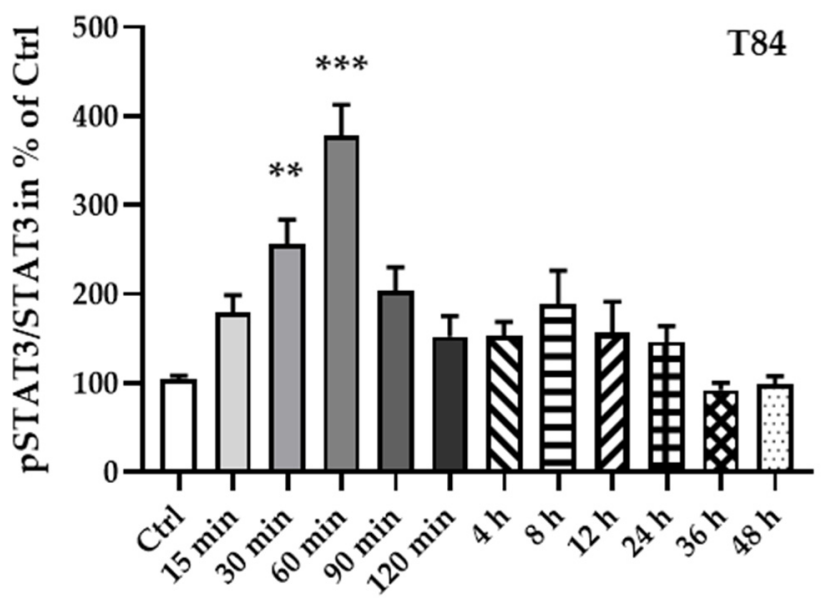

(a)

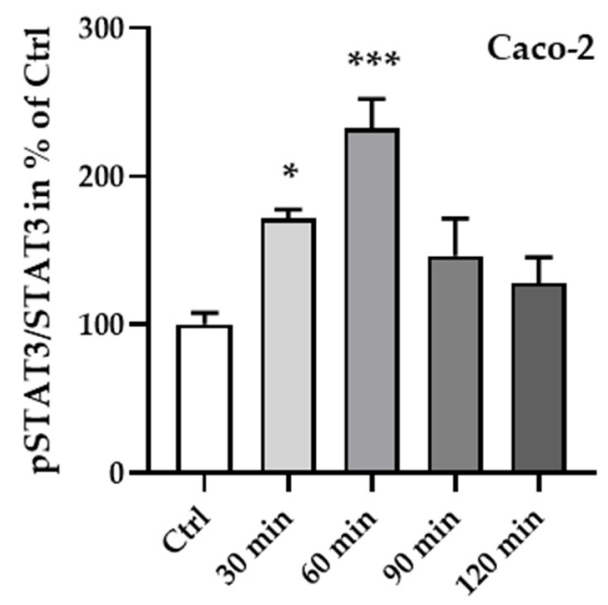

(b)

Figure 8. Phosphorylated STAT3 to total STAT3 ratio at different time points of leptin treatment in T84 (a) and Caco-2 cells (b). The phosphorylation of STAT3 becomes significant after 30 min of leptin treatment and peaks at $60 \mathrm{~min}$ in both cell lines. ${ }^{*} p<0.05,{ }^{* *} p<0.01,{ }^{* * *} p<0.001, n=6-11$.

Next, STAT3 inhibitors, Stattic and WP1066, and the JAK2 inhibitor AG490, which showed an inhibitory effect to leptin treatment, were applied for $1 \mathrm{~h}$ before leptin treatment. Similar to the effects seen on angulin-1 expression in both cell lines, Stattic as well as WP1066 inhibited the phosphorylation of STAT3 (Figure $9 \mathrm{a}, \mathrm{b},{ }^{* * *} p<0.001, n=6-8$ ), whereas AG490 only showed a partial effect (Figure $9 \mathrm{a}$, ** $p<0.01, n=8$; Figure $9 \mathrm{~b},{ }^{*} p<0.05, n=6$ ).

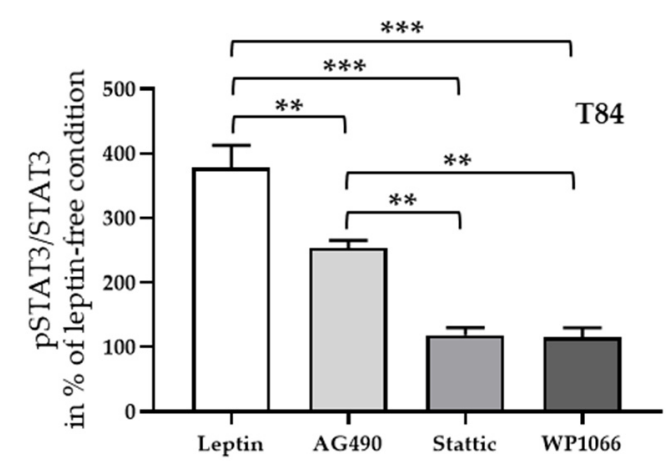

(a)

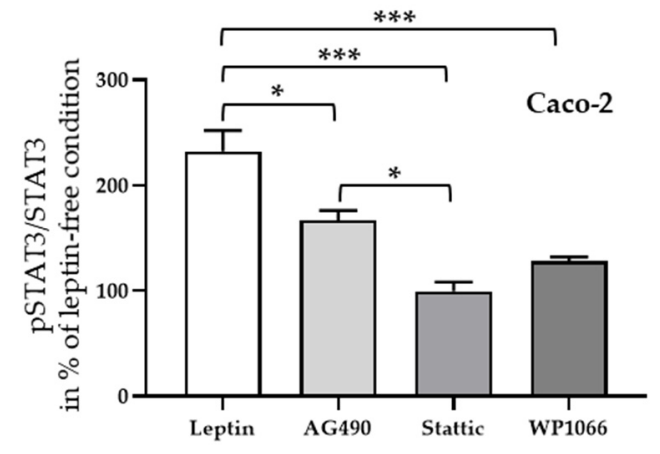

(b)

Figure 9. Effect of inhibitors on phosphorylated STAT3 to total STAT3 ratio in T84 (a) and in Caco-2 cells (b). ${ }^{*} p<0.05,{ }^{* *} p<0.01,{ }^{* * *} p<0.001, n=6-8$.

\section{Discussion}

\subsection{The Involvement of Angulin-1 in CD}

The $\mathrm{tTJ}$ is a special arrangement of TJ strands at the contacts of where three or more cells meet. The structure of the tTJ forms a vertically extended ladder-like meshwork and has been assumed to be a weak point of paracellular barriers [11]. Tricellulin and the angulin family are the two major components of tTJs and have been shown to be involved in maintaining the barrier of the tTJ. While 
angulins are responsible for the correct localization of tricellulin, this protein tightens the tTJ against macromolecule passage $[14,15,40]$.

Despite the difference of the principal angulin expression in different tissues, angulin- 1 is the major one in the base of crypts, while the expression of angulin-2 fills the vacancy of the upper part of crypts [16].

In a previous study analyzing human sigmoid colon samples it was found that tricellulin retained the same protein expression level in CD and control patients, yet further investigation of tricellulin localization revealed a mild decrease within crypts but an increase in surface epithelium [15]. This shifted localization suggested that the regulation of tricellulin in CD might involve regulators, and that this alteration of tTJs might be more sophisticated. For this purpose, the expression of angulins was analyzed in CD. We show here that angulin-1 was downregulated specifically in active CD compared to controls as well as CD patients in remission. Angulin-2 and -3 were unaltered; however, due to the insufficient quality of the available antibodies against angulin- 2 and -3 , these two proteins could only be analyzed at the mRNA level.

\subsection{Leptin Affecting the Expression of Angulin-1}

To elucidate the mechanisms behind the downregulation of angulin-1 in $C D$, leptin, among the total twelve cytokines, which have been reported to be mainly involved in $C D$, was found to be the only one leading to a decrease in angulin- 1 in the intestinal cell lines T84 and Caco-2. The involvement of leptin was consistent with its enhanced effects on Th1 as well as Th17 cytokines and also with the hypertrophic MAT in CD [41].

Analyzing the functional effect of the leptin treatment and thus angulin-1 downregulation, we observed that permeability for FD4 was increased in Caco-2 cells but not in T84 cells. This difference might be explained by the different permeability for FD4 in these two cell lines. Untreated Caco-2 cells have a lower permeability for FD4 compared to T84 cells. After treatment, the permeability increased to levels comparable of that of the untreated T84, which could suggest that this was already the maximum increase to be expected in such conditions and concentration, so that the difference is detectable in CaCo-2 cells, but not in T84. In a tissue similar to the intestinal crypt a well-balanced barrier is essential, so the impaired tTJ may be of bigger impact for the total macromolecular barrier than data from intestinal monolayers would suggest.

We did not observe localization changes of tricellulin in both T84 and Caco-2 cells using confocal laser scanning microscopy. This seems to be contradictory to the previous finding that the knockdown of angulin-1 resulted in a deviation of tricellulin from tTJs [18]. However, this experiment was performed under the circumstance of an extreme knockdown of angulin- 1 while, in our present study, leptin only led to a downregulation of $40-50 \%$ of angulin- 1 . Furthermore, a quantification of the tricellular signals of tricellulin stainings was not performed as for this a strict calibration was needed. Our study might further indicate that a halved expression of angulin-1 is still sufficient to hold tricellulin in position, but the barrier becomes vulnerable compared to full angulin-1 expression as we did demonstrate an increased permeability for FD4 in Caco-2 cells. Interaction of tricellulin with other tricellulin molecules and angulin- 1 could also not be visualized directly. This interaction might be reduced and thus lead to the observed weakening of the barrier. In addition, we did not analyze effects of the other angulins that could also keep tricellulin in place but were reported to be insufficient in keeping the barrier function [16], as the antibodies for these proteins are not of good quality and mRNA expression would not give any information about the actual interaction and localization of the proteins.

\subsection{Leptin-Regulated Downregulation of Angulin-1 via STAT3 Pathway}

Leptin usually signals via its three types of receptor isoforms: (i) the long isoform which contains an extracellular binding domain, a single transmembrane domain and an intracellular signaling domain [42], (ii) the short isoform which has three variants in humans and which lacks part of the 
cytoplasmic region, and (iii) the soluble isoform which is a cleavage product of the long isoform for binding circulating leptin [43].

Leptin receptors (LRs) are reported to lack intrinsic kinase activity; instead, the signal transduction has to process through the binding of Janus kinase (JAK) 2 and the phosphorylation of tyrosine sites downstream of the LR/JAK2 complex [37]. Therefore, above all sorts of LRs, the long-form LR is assumed to be most important in transducing leptin signals due to the fact that besides the binding motif for JAK2, it is the only isoform containing three tyrosine phosphorylation sites (Tyr986, Tyr1079 and Tyr1141 in humans [43] or Tyr985, Tyr1077 and Tyr1138 in rodents [44]).

Tyr985 binds to the Src-homology-2 domain protein (SHP-2) activating the ERK signaling pathway which mediates the regulation of c-fos message [38]. Tyr1077 activates STAT5 signaling acting on the reproduction effect of leptin [44]. Tyr1138 not only has the ability to phosphorylate STAT5, but also mediates STAT3 regulation, which could be subsequently inhibited by the interaction between the suppressor of cytokine signaling 3 (SOCS3) and Tyr985 [45] or JAK2 itself [46]. In addition, the involvement of PI3K was exhibited during the regulation of energy consumption in the central nerve system [39]. Leptin could also induce an anti-apoptotic effect through PI3K as well as mitogen-activated protein kinase (MAPK) pathways [47], which consequently enhanced Th1 and Th17 responses and promoted a proinflammatory effect [48-50].

Using different inhibitors, we show that the downregulation of angulin-1 induced by leptin was blocked by pre-treatment with AG490, Stattic or WP1066. Furthermore, phosphorylation experiments also revealed that STAT3 was phosphorylated after leptin treatment. These results confirmed the involvement of JAK2 and STAT3, but the incomplete blockage of AG490 suggested that leptin-activating STAT3 might not necessarily signal via JAK2.

\subsection{Concluding Remarks}

Leptin-1 is an important factor in fat metabolism, and angulin-1 was initially found to be involved in lipid clearance [17]. In line with our observed permeability change, a recent study reported that administration of lipid micelles in Caco-2 cells was able to cause an enhanced passage of macromolecules ( $>4 \mathrm{kDa}$ ). Lipid micelles decreased tricellulin content within $\mathrm{tTJs}$, which also links tricellulin and the tTJ to lipid metabolism, presumably due to angulin-1 as a regulator [51].

One characteristic of CD is the appearance of "creeping fat", a thickened mesenteric fat tissue located close to the inflamed parts of the intestine [5], pointing towards disturbed fat metabolism. Importantly, creeping fat is a source of leptin [6-8].

Here we show that angulin- 1 is affected in the process of active $C D$, which can be driven by leptin via the STAT3 signaling pathway.

As an invasion of macromolecules (e.g., pathogens) might be an important reason in the relapse of $\mathrm{CD}$, restoring the expression of angulin-1 might help tighten the intestinal barrier and break the loop of impaired barrier and increased uptake of pathogens. Therefore, targeting leptin as well as angulin-1 regulation might be potential approaches for new $\mathrm{CD}$ treatments.

\section{Materials and Methods}

\subsection{Patients and Study Criteria}

CD patients and patients without intestinal diseases visiting the endoscopy center of the Department of Gastroenterology, Rheumatology and Infectious Diseases, Charité-Universitätsmedizin were enrolled to the study with prior consent. The diagnosis of $C D$ was based on the standard criteria [52] and the endoscopic activity was evaluated using simple endoscopic score for CD (SES-CD) [36]. The study was approved by the local ethics committee (No. EA4/015/13).

Exclusion criteria were: age below 18 or above 80 years, pregnancy, presence of other major diseases (neoplastic diseases, other immunological diseases and chronic inflammatory diseases), biotic treatment, presence of fistula or perforation, need of surgery, lack of consent to the study. 
Healthy controls were patients free of gastrointestinal diseases (e.g., IBD, irritable bowel syndrome, diarrhea, preceding gastrointestinal surgery) and other major conditions described above.

\subsection{Cell Lines}

Two human intestinal epithelial cell lines, T84 cells (ATCC ${ }^{\circledR}$ CCL-248 ${ }^{\mathrm{TM}}$ ), and Caco-2 cells (ATCC ${ }^{\circledR}$ HTB-37' ${ }^{\mathrm{TM}}$ ) were cultured at $37^{\circ} \mathrm{C}$ in a $5 \% \mathrm{CO}_{2}$ air atmosphere. For cultivating, $25 \mathrm{~cm}^{2}$ culture flasks were used and complete growth mediums for these three cell lines are listed in Table 2. Medium was renewed every two to three days.

Table 2. Complete growth mediums for different cell lines.

\begin{tabular}{cccc}
\hline Cell Line & Basic Medium & Source & Supplements \\
\hline \multirow{2}{*}{ T84 } & DMEM: F-12 medium & Sigma-Aldrich, & $10 \% \mathrm{FBS}, 100 \mathrm{U} / \mathrm{mL}$ penicillin, \\
& & Steinheim, Germany & $100 \mu \mathrm{g} / \mathrm{mL}$ streptomycin \\
Caco-2 & MEM with glutamax & Sigma-Aldrich, & $15 \% \mathrm{FBS}, 100 \mathrm{U} / \mathrm{mL}$ penicillin, \\
& & Steinheim, Germany & $100 \mu \mathrm{g} / \mathrm{mL}$ streptomycin \\
\hline
\end{tabular}

For experiments, $4 \times 10^{5}$ cells were seeded onto $3 \mu \mathrm{m}$-pore-size (T84 cells, effective area $0.6 \mathrm{~cm}^{2}$, Millipore, MA, USA) or $0.4 \mu \mathrm{m}$-pore-size (Caco-2 cells, effective area $0.6 \mathrm{~cm}^{2}$, Millipore, MA, USA) cell culture inserts. Confluent and well-differentiated cell monolayers were used 8 days (T84), and 14 days (Caco-2) after seeding.

\subsection{Cytokines and Inhibitors Experiments}

For cytokine treatments, cells were incubated with the cytokines listed in Table 3 for 24 (TNF $\alpha)$ or $48 \mathrm{~h}$ (all the other cytokines). For inhibitor experiments, a $1 \mathrm{~h}$ pre-treatment was performed prior to leptin treatment at a listed concentration. For $96 \mathrm{~h}$ of leptin treatment with or without inhibitors, the medium was renewed after $48 \mathrm{~h}$ along with the same concentration of leptin and corresponding inhibitors.

Table 3. Cytokines and inhibitors.

\begin{tabular}{ccc}
\hline & Concentration & Source \\
\hline Cytokines & & \\
TNF $\alpha$ & $500 \mathrm{U} / \mathrm{mL}$ & PeproTech, Hamburg, Germany \\
IFN $\gamma$ & $1000 \mathrm{U} / \mathrm{mL}$ & PeproTech, Hamburg, Germany \\
Leptin & $200 \mathrm{ng} / \mathrm{mL}$ & PeproTech, Hamburg, Germany \\
IL-1 $\beta$ & $100 \mathrm{ng} / \mathrm{mL}$ & PeproTech, Hamburg, Germany \\
IL-6 & $10 \mathrm{ng} / \mathrm{mL}$ & Miltenyi Biotec, Bergisch Gladbach, Germany \\
IL-12 & $100 \mathrm{ng} / \mathrm{mL}$ & PeproTech, Hamburg, Germany \\
IL-17A & $100 \mathrm{ng} / \mathrm{mL}$ & PeproTech, Hamburg, Germany \\
IL-17F & $100 \mathrm{ng} / \mathrm{mL}$ & Miltenyi Biotec, Bergisch Gladbach, Germany \\
IL-21 & $100 \mathrm{ng} / \mathrm{mL}$ & Miltenyi Biotec, Bergisch Gladbach, Germany \\
IL-22 & $50 \mathrm{ng} / \mathrm{mL}$ & PeproTech, Hamburg, Germany \\
IL-23 & $100 \mathrm{ng} / \mathrm{mL}$ & PeproTech, Hamburg, Germany \\
IL-33 & $100 \mathrm{ng} / \mathrm{mL}$ & Miltenyi Biotec, Bergisch Gladbach, Germany \\
Inhibitors & & \\
AG490 & $100 \mu \mathrm{M}$ & Calbiochem, Darmstadt, Germany \\
LY294002 & $10 \mu \mathrm{M}$ & Calbiochem, Darmstadt, Germany \\
Stattic & $20 \mu \mathrm{M}$ & Calbiochem, Darmstadt, Germany \\
U0126 & $10 \mu \mathrm{M}$ & Calbiochem, Darmstadt, Germany \\
WP1066 & $5 \mu \mathrm{M}$ &
\end{tabular}




\subsection{Western Blotting}

For isolation of protein from formalin-fixed paraffin-embedded (FFPE) sections, a Qproteome FFPE Tissue Kit (QIAGEN, Hilden, Germany) was used. FFPE Intestinal biopsies were acquired from sample stocks in the Institute for protein preparation. The protein extraction process was carried out according to the manufacturer's instruction. RNA and protein were extracted in parallel using a NucleoSpin RNA/Protein kit (Macherey-Nagel, Düren, Germany). The concentration of protein was determined using a bicinchoninic acid (BCA) protein assay. Total protein from cell culture, phosphorylation assay, and Western blotting were performed as previously described [15]. The primary antibodies applied in the study were rabbit anti-angulin-1 (1:3000, Sigma-Aldrich, Schnelldorf, Germany), rabbit anti-tricellulin (1:2000, Invitrogen, Karlsruhe, Germany), rabbit anti-Cldn-2 (1:1000, Invitrogen, Karlsruhe, Germany), mouse anti-Cldn-4 (1:1000, Invitrogen, Karlsruhe, Germany), mouse anti- $\beta$-actin (1:10,000, Invitrogen, Karlsruhe, Germany), rabbit anti-STAT3 and rabbit anti-phospho-STAT3 (1:1000, Cell Signaling Technology). For secondary antibodies, peroxidase-conjugated goat anti-rabbit or -mouse IgG (Jackson ImmunoResearch, Ely, UK) was used. Image detection was performed with incubation with a SuperSignal West Pico Plus Stable Peroxide solution (Thermo Fisher, Mannheim, Germany) and exposure in a Fusion FX7 (Vilber Lourmat, Eberhardzell, Germany). Densitometric analysis was performed using Multi Gauge V2.3 software (FujiFilm, Düsseldorf, Germany). The expression of angulin-1, tricellulin, Cldn-2 and Cldn-4 was quantified after normalization of the respective band intensities using $\beta$-actin.

\subsection{RNA Isolation, Reverse Transcription, and Quantitative Real-Time PCR ( $q R T-P C R$ )}

The isolation of RNA was described previously [15]. Reverse transcription was performed using a High Capacity cDNA Reverse Transcription kit (Thermo Fisher, Mannheim, Germany). Angulin-1 (Hs01076323_m1), angulin-2 (Hs01111433_m1), angulin-3 (Hs01025498_m1), tricellulin (Hs00930631_m1), Cldn-2 (Hs00252666_s1), Cldn-4 (Hs00533616_s1), and GAPDH (Hs02786624_g1) TaqMan ${ }^{\circledR}$ probes were used in qRT-PCR. A relative method according to the $2^{-\Delta \Delta C T}$ method was applied for expression analysis.

\subsection{Immunofluorescent Staining}

After leptin treatment, the cell monolayers were fixed with 2\% PFA, quenched with $25 \mathrm{mM}$ glycine, permeabilized using $0.5 \%$ Triton X-100, and blocked with $5 \%$ goat serum. The cells were stained with the following primary antibodies: rabbit anti-angulin-1 (1:1500, Sigma-Aldrich, Schnelldorf, Germany), rabbit anti-tricellulin (1:1000, Invitrogen, Karlsruhe, Germany), and mouse anti-ZO-1 (1:500, Invitrogen, Karlsruhe, Germany). Alexa Fluor 488 goat anti-rabbit and Alexa Fluor 594 goat anti-mouse (1:500 each, Molecular Probes MoBiTec, Göttingen, Germany) were used as secondary antibodies. 4',6-Diamidino-2-phenylindole (DAPI, 1:1000) was used to stain nuclei. Fluorescence images were acquired by a confocal laser scanning microscope (LSM 780, Carl Zeiss, Jena, Germany).

\subsection{Electrophysiological and Paracellular Flux Measurements}

Electrophysiological features were measured in Ussing chambers as described before [53]. For measuring FD4 fluxes, $0.4 \mathrm{mM}$ of pre-dialyzed FITC-dextran $4 \mathrm{kDa}$ (TdB Consultancy, Sweden) in apical hemi-chamber and $0.4 \mathrm{mM}$ unlabeled dextran $4 \mathrm{kDa}$ (Serva, Heidelberg, Germany) in basolateral side were applied. The measurements were carried out at $520 \mathrm{~nm}$ using a spectrometer (Tecan Infinite M200, Tecan, Switzerland) on basolateral samples taken at 0, 30, 60, 90, and 120 min after addition from the unlabeled side. 


\subsection{Statistical Analysis}

Data are expressed as mean values \pm standard error of the mean (SEM). Statistical analyses were performed using a Student's $t$-test for comparison between two groups or one-way ANOVA for comparing more than two groups (multiple testing). $p<0.05$ was considered significant.

Supplementary Materials: Supplementary Materials can be found at http://www.mdpi.com/1422-0067/21/21/ 7824/s1.

Author Contributions: Conceptualization, J.H., S.K., M.F.; investigation, J.H., S.K., C.B., F.B.; writing一original draft preparation, J.H., S.K.; writing-review and editing, S.K., M.F., C.B., F.B.; funding acquisition, S.K., M.F. All authors have read and agreed to the published version of the manuscript.

Funding: This research was funded by the Deutsche Forschungsgemeinschaft (DFG) Graduiertenkolleg, "TJ-train", GRK 2318, and the Open Access Publication Funds of Charité - Universitätsmedizin Berlin.

Acknowledgments: We would like to thank the excellent support by the central endoscopy department of Campus Benjamin Franklin, Charité-Universitätsmedizin Berlin. Additionally, we thank for the technical assistance of In-Fah M. Lee, Britta Jebautzke, and Anja Fromm of Institute of Clinical Physiology/Nutritional Medicine.

Conflicts of Interest: The authors declare no conflict of interest.

\section{Abbreviations}

$\begin{array}{ll}\text { bTJ } & \text { Bicellular tight junction } \\ \text { CD } & \text { Crohn's disease } \\ \text { Cldn } & \text { Claudin } \\ \text { DAPI } & 4^{\prime} \text {,6-diamidino-2-phenylindole } \\ \text { ERK } & \text { Extracellular signal-regulated kinases } \\ \text { FD4 } & \text { FITC-dextran } 4 \text { kDa } \\ \text { FFPE } & \text { Formalin-fixed paraffin-embedded } \\ \text { FITC } & \text { Fluorescein isothiocyanate } \\ \text { IBD } & \text { Inflammatory bowel disease } \\ \text { IFN } & \text { Interferon } \\ \text { IL } & \text { Interleukin } \\ \text { JAK } & \text { Janus kinase } \\ \text { LR } & \text { Leptin receptor } \\ \text { LSM } & \text { Lasor scanning microscope } \\ \text { LSR } & \text { Lipolysis-stimulated lipoprotein receptor } \\ \text { MAPK } & \text { Mitogen-activated protein kinase } \\ \text { PI3K } & \text { Phosphoinositide 3-kinase } \\ \text { SES-CD } & \text { Simple endoscopic score for CD } \\ \text { STAT } & \text { Signal transducer and activator of transcription } \\ \text { TER } & \text { Transepithelial resistance } \\ \text { TJ } & \text { Tight junction } \\ \text { tTJ } & \text { Tricellular tight junction } \\ \text { TNF } & \text { Tumor necrosis factor } \\ \end{array}$

\section{References}

1. Ng, S.C.; Shi, H.Y.; Hamidi, N.; Underwood, F.E.; Tang, W.; Benchimol, E.I.; Panaccione, R.; Ghosh, S.; $\mathrm{Wu}$, J.C.Y.; Chan, F.K.L.; et al. Worldwide incidence and prevalence of inflammatory bowel disease in the 21st century: A systematic review of population-based studies. Lancet 2017, 390, 2769-2778. [CrossRef]

2. Kaplan, G.G.; Ng, S.C. Understanding and Preventing the Global Increase of Inflammatory Bowel Disease. Gastroenterology 2017, 152, 313-321.e2. [CrossRef] [PubMed]

3. Martini, E.; Krug, S.M.; Siegmund, B.; Neurath, M.F.; Becker, C. Mend Your Fences: The Epithelial Barrier and its Relationship With Mucosal Immunity in Inflammatory Bowel Disease. Cell Mol. Gastroenterol. Hepatol. 2017, 4, 33-46. [CrossRef] [PubMed]

4. Trayhurn, P.; Wood, I.S. Adipokines: Inflammation and the pleiotropic role of white adipose tissue. Br. J. Nutr. 2004, 92, 347-355. [CrossRef] 
5. Crohn, B.B.; Ginzburg, L.; Oppenheimer, G.D. Regional ileitis: A pathologic and clinical entity. Am. J. Med. 1952, 13, 583-590. [CrossRef]

6. Sitaraman, S.; Liu, X.; Charrier, L.; Gu, L.H.; Ziegler, T.R.; Gewirtz, A.; Merlin, D. Colonic leptin: Source of a novel proinflammatory cytokine involved in IBD. FASEB J. 2004, 18, 696-698. [CrossRef]

7. Barbier, M.; Vidal, H.; Desreumaux, P.; Dubuquoy, L.; Bourreille, A.; Colombel, J.F.; Cherbut, C.; Galmiche, J.P. Overexpression of leptin mRNA in mesenteric adipose tissue in inflammatory bowel diseases. Gastroenterol. Clin. Biol. 2003, 27, 987-991. [CrossRef]

8. Paul, G.; Schäffler, A.; Neumeier, M.; Fürst, A.; Bataillle, F.; Buechler, C.; Müller-Ladner, U.; Schölmerich, J.; Rogler, G.; Herfarth, H. Profiling adipocytokine secretion from creeping fat in Crohn's disease. Inflamm. Bowel Dis. 2006, 12, 471-477. [CrossRef]

9. Diamond, J.M. Twenty-first Bowditch lecture. The epithelial junction: Bridge, gate, and fence. Physiologist 1977, 20, 10-18.

10. Farquhar, M.G.; Palade, G.E. Cell junctions in amphibian skin. J. Cell. Biol. 1965, 26, 263-291. [CrossRef]

11. Staehelin, L.A.; Mukherjee, T.M.; Williams, A.W. Freeze-etch appearance of the tight junctions in the epithelium of small and large intestine of mice. Protoplasma 1969, 67, 165-184. [CrossRef] [PubMed]

12. Staehelin, L.A. Further observations on the fine structure of freeze-cleaved tight junctions. J. Cell. Sci. 1973, 13, 763-786. [PubMed]

13. Ikenouchi, J.; Furuse, M.; Furuse, K.; Sasaki, H.; Tsukita, S.; Tsukita, S. Tricellulin constitutes a novel barrier at tricellular contacts of epithelial cells. J. Cell. Biol. 2005, 171, 939-945. [CrossRef] [PubMed]

14. Krug, S.M.; Amasheh, S.; Richter, J.F.; Milatz, S.; Gunzel, D.; Westphal, J.K.; Huber, O.; Schulzke, J.D.; Fromm, M. Tricellulin forms a barrier to macromolecules in tricellular tight junctions without affecting ion permeability. Mol. Biol. Cell. 2009, 20, 3713-3724. [CrossRef] [PubMed]

15. Krug, S.M.; Bojarski, C.; Fromm, A.; Lee, I.M.; Dames, P.; Richter, J.F.; Turner, J.R.; Fromm, M.; Schulzke, J.D. Tricellulin is regulated via interleukin-13-receptor alpha2, affects macromolecule uptake, and is decreased in ulcerative colitis. Mucosal. Immunol. 2018, 11, 345-356. [CrossRef]

16. Higashi, T.; Tokuda, S.; Kitajiri, S.; Masuda, S.; Nakamura, H.; Oda, Y.; Furuse, M. Analysis of the 'angulin' proteins LSR, ILDR1 and ILDR2-Tricellulin recruitment, epithelial barrier function and implication in deafness pathogenesis. J. Cell. Sci. 2013, 126 (Pt 4), 966-977. [CrossRef]

17. Yen, F.T.; Mann, C.J.; Guermani, L.M.; Hannouche, N.F.; Hubert, N.; Hornick, C.A.; Bordeau, V.N.; Agnani, G.; Bihain, B.E. Identification of a lipolysis-stimulated receptor that is distinct from the LDL receptor and the LDL receptor-related protein. Biochemistry 1994, 33, 1172-1180. [CrossRef]

18. Masuda, S.; Oda, Y.; Sasaki, H.; Ikenouchi, J.; Higashi, T.; Akashi, M.; Nishi, E.; Furuse, M. LSR defines cell corners for tricellular tight junction formation in epithelial cells. J. Cell. Sci. 2011, 124 (Pt 4), 548-555. [CrossRef]

19. El Hajj, A.; Yen, F.T.; Oster, T.; Malaplate, C.; Pauron, L.; Corbier, C.; Lanhers, M.-C.; Claudepierre, T. Age-related changes in regiospecific expression of Lipolysis Stimulated Receptor (LSR) in mice brain. PLOS ONE 2019, 14, e0218812. [CrossRef]

20. Xie, T.; Stathopoulou, M.G.; Akbar, S.; Oster, T.; Siest, G.; Yen, F.T.; Visvikis-Siest, S. Effect of LSR polymorphism on blood lipid levels and age-specific epistatic interaction with the APOE common polymorphism. Clin. Genet. 2018, 93, 846-852. [CrossRef]

21. Akbar, S.; Pincon, A.; Lanhers, M.C.; Claudepierre, T.; Corbier, C.; Gregory-Pauron, L.; Malaplate-Armand, C.; Visvikis, A.; Oster, T.; Yen, F.T. Expression profile of hepatic genes related to lipid homeostasis in LSR heterozygous mice contributes to their increased response to high-fat diet. Physiol. Genom. 2016, 48, 928-935. [CrossRef] [PubMed]

22. Xie, T.; Akbar, S.; Stathopoulou, M.G.; Oster, T.; Masson, C.; Yen, F.T.; Visvikis-Siest, S. Epistatic interaction of apolipoprotein E and lipolysis-stimulated lipoprotein receptor genetic variants is associated with Alzheimer's disease. Neurobiol. Aging 2018, 69, 292.e1-292.e5. [CrossRef]

23. Sugase, T.; Takahashi, T.; Serada, S.; Fujimoto, M.; Ohkawara, T.; Hiramatsu, K.; Koh, M.; Saito, Y.; Tanaka, K.; Miyazaki, Y.; et al. Lipolysis-stimulated lipoprotein receptor overexpression is a novel predictor of poor clinical prognosis and a potential therapeutic target in gastric cancer. Oncotarget 2018, 9, 32917-32928. [CrossRef]

24. Hiramatsu, K.; Serada, S.; Enomoto, T.; Takahashi, Y.; Nakagawa, S.; Nojima, S.; Morimoto, A.; Matsuzaki, S.; Yokoyama, T.; Takahashi, T.; et al. LSR Antibody Therapy Inhibits Ovarian Epithelial Tumor Growth by Inhibiting Lipid Uptake. Cancer Res. 2018, 78, 516-527. [CrossRef] 
25. Shimada, H.; Abe, S.; Kohno, T.; Satohisa, S.; Konno, T.; Takahashi, S.; Hatakeyama, T.; Arimoto, C.; Kakuki, T.; Kaneko, Y.; et al. Loss of tricellular tight junction protein LSR promotes cell invasion and migration via upregulation of TEAD1/AREG in human endometrial cancer. Sci. Rep. 2017, 7, 37049. [CrossRef] [PubMed]

26. Shimada, H.; Satohisa, S.; Kohno, T.; Konno, T.; Takano, K.-I.; Takahashi, S.; Hatakeyama, T.; Arimoto, C.; Saito, T.; Kojima, T. Downregulation of lipolysis-stimulated lipoprotein receptor promotes cell invasion via claudin-1-mediated matrix metalloproteinases in human endometrial cancer. Oncol. Lett. 2017, 14, 6776-6782. [CrossRef] [PubMed]

27. Shimada, H.; Satohisa, S.; Kohno, T.; Takahashi, S.; Hatakeyama, T.; Konno, T.; Tsujiwaki, M.; Saito, T.; Kojima, T. The roles of tricellular tight junction protein lipolysis-stimulated lipoprotein receptor in malignancy of human endometrial cancer cells. Oncotarget 2016, 7, 27735-27752. [CrossRef]

28. Reaves, D.K.; Fagan-Solis, K.D.; Dunphy, K.; Oliver, S.D.; Scott, D.W.; Fleming, J.M. The role of lipolysis stimulated lipoprotein receptor in breast cancer and directing breast cancer cell behavior. PLoS ONE 2014, 9, e91747. [CrossRef]

29. Reaves, D.K.; Hoadley, K.A.; Fagan-Solis, K.D.; Jima, D.D.; Bereman, M.; Thorpe, L.; Hicks, J.; McDonald, D.; Troester, M.A.; Perou, C.M.; et al. Nuclear Localized LSR: A Novel Regulator of Breast Cancer Behavior and Tumorigenesis. Mol. Cancer Res. 2017, 15, 165-178. [CrossRef]

30. García, J.M.; Peña, C.; García, V.; Domínguez, G.; Muñoz, C.; Silva, J.; Millán, I.; Diaz, R.; Lorenzo, Y.; Rodriguez, R.; et al. Prognostic value of LISCH7 mRNA in plasma and tumor of colon cancer patients. Clin. Cancer Res. 2007, 13, 6351-6358. [CrossRef]

31. Nagahama, M.; Takehara, M.; Kobayashi, K. Interaction of Clostridium perfringens Iota Toxin and Lipolysis-Stimulated Lipoprotein Receptor (LSR). Toxins (Basel) 2018, 10, 405. [CrossRef]

32. Hemmasi, S.; Czulkies, B.A.; Schorch, B.; Veit, A.; Aktories, K.; Papatheodorou, P. Interaction of the Clostridium difficile Binary Toxin CDT and Its Host Cell Receptor, Lipolysis-stimulated Lipoprotein Receptor (LSR). J. Biol. Chem. 2015, 290, 14031-14044. [CrossRef] [PubMed]

33. Stenger, C.; Hanse, M.; Pratte, D.; Mbala, M.L.; Akbar, S.; Koziel, V.; Escanye, M.C.; Kriem, B.; Malaplate-Armand, C.; Olivier, J.L.; et al. Up-regulation of hepatic lipolysis stimulated lipoprotein receptor by leptin: A potential lever for controlling lipid clearance during the postprandial phase. Faseb J. 2010, 24, 4218-4228. [CrossRef]

34. Krug, S.M.; Schulzke, J.D.; Fromm, M. Tight junction, selective permeability, and related diseases. Semin. Cell. Dev. Biol. 2014, 36, 166-176. [CrossRef]

35. Zeissig, S.; Burgel, N.; Gunzel, D.; Richter, J.; Mankertz, J.; Wahnschaffe, U.; Kroesen, A.J.; Zeitz, M.; Fromm, M.; Schulzke, J.D. Changes in expression and distribution of claudin 2, 5 and 8 lead to discontinuous tight junctions and barrier dysfunction in active Crohn's disease. Gut 2007, 56, 61-72. [CrossRef] [PubMed]

36. Daperno, M.; D’Haens, G.; Van Assche, G.; Baert, F.; Bulois, P.; Maunoury, V.; Sostegni, R.; Rocca, R.; Pera, A.; Gevers, A.; et al. Development and validation of a new, simplified endoscopic activity score for Crohn's disease: The SES-CD. Gastrointest. Endosc. 2004, 60, 505-512. [CrossRef]

37. Myers, M.G.; Cowley, M.A.; Munzberg, H. Mechanisms of leptin action and leptin resistance. Annu. Rev. Physiol. 2008, 70, 537-556. [CrossRef]

38. Banks, A.S.; Davis, S.M.; Bates, S.H.; Myers, M.G., Jr. Activation of downstream signals by the long form of the leptin receptor. J. Biol. Chem. 2000, 275, 14563-14572. [CrossRef]

39. Plum, L.; Rother, E.; Munzberg, H.; Wunderlich, F.T.; Morgan, D.A.; Hampel, B.; Shanabrough, M.; Janoschek, R.; Konner, A.C.; Alber, J.; et al. Enhanced leptin-stimulated Pi3k activation in the CNS promotes white adipose tissue transdifferentiation. Cell. Metab. 2007, 6, 431-445. [CrossRef]

40. Krug, S.M. Contribution of the tricellular tight junction to paracellular permeability in leaky and tight epithelia. Ann. N. Y. Acad. Sci. 2017, 1397, 219-230. [CrossRef]

41. Weidinger, C.; Ziegler, J.F.; Letizia, M.; Schmidt, F.; Siegmund, B. Adipokines and Their Role in Intestinal Inflammation. Front. Immunol. 2018, 9, 1974. [CrossRef] [PubMed]

42. Tartaglia, L.A. The leptin receptor. J. Biol. Chem. 1997, 272, 6093-6096. [CrossRef] [PubMed]

43. Schaab, M.; Kratzsch, J. The soluble leptin receptor. Best Pract. Res. Clin. Endocrinol. Metab. 2015, 29, 661-670. [CrossRef]

44. Hekerman, P.; Zeidler, J.; Bamberg-Lemper, S.; Knobelspies, H.; Lavens, D.; Tavernier, J.; Joost, H.G.; Becker, W. Pleiotropy of leptin receptor signalling is defined by distinct roles of the intracellular tyrosines. Febs J. 2005, 272, 109-119. [CrossRef] [PubMed] 
45. Bjorbak, C.; Lavery, H.J.; Bates, S.H.; Olson, R.K.; Davis, S.M.; Flier, J.S.; Myers, M.G., Jr. SOCS3 mediates feedback inhibition of the leptin receptor via Tyr985. J. Biol. Chem. 2000, 275, 40649-40657. [CrossRef]

46. Sasaki, A.; Yasukawa, H.; Shouda, T.; Kitamura, T.; Dikic, I.; Yoshimura, A. CIS3/SOCS-3 suppresses erythropoietin (EPO) signaling by binding the EPO receptor and JAK2. J. Biol. Chem. 2000, 275, 29338-29347. [CrossRef]

47. Bruno, A.; Conus, S.; Schmid, I.; Simon, H.U. Apoptotic pathways are inhibited by leptin receptor activation in neutrophils. J. Immunol. 2005, 174, 8090-8096. [CrossRef]

48. Fernández-Riejos, P.; Goberna, R.; Sánchez-Margalet, V. Leptin promotes cell survival and activates Jurkat $\mathrm{T}$ lymphocytes by stimulation of mitogen-activated protein kinase. Clin. Exp. Immunol. 2008, 151, 505-518. [CrossRef]

49. Lord, G.M.; Matarese, G.; Howard, J.K.; Baker, R.J.; Bloom, S.R.; Lechler, R.I. Leptin modulates the T-cell immune response and reverses starvation-induced immunosuppression. Nature 1998, 394, 897-901. [CrossRef]

50. Yu, Y.; Liu, Y.; Shi, F.D.; Zou, H.; Matarese, G.; La Cava, A. Cutting edge: Leptin-induced ROR $\gamma \mathrm{t}$ expression in CD4+ T cells promotes Th17 responses in systemic lupus erythematosus. J. Immunol. 2013, 190, 3054-3058. [CrossRef]

51. Genser, L.; Aguanno, D.; Soula, H.A.; Dong, L.; Trystram, L.; Assmann, K.; Salem, J.E.; Vaillant, J.C.; Oppert, J.M.; Laugerette, F.; et al. Increased jejunal permeability in human obesity is revealed by a lipid challenge and is linked to inflammation and type 2 diabetes. J. Pathol. 2018, 246, 217-230. [CrossRef] [PubMed]

52. Gomollon, F.; Dignass, A.; Annese, V.; Tilg, H.; Van Assche, G.; Lindsay, J.O.; Peyrin-Biroulet, L.; Cullen, G.J.; Daperno, M.; Kucharzik, T.; et al. European Evidence-based Consensus on the Diagnosis and Management of Crohn's Disease 2016: Part 1: Diagnosis and Medical Management. J. Crohns Colitis 2017, 11, 3-25. [CrossRef] [PubMed]

53. Kreusel, K.M.; Fromm, M.; Schulzke, J.D.; Hegel, U. Cl- secretion in epithelial monolayers of mucus-forming human colon cells (HT-29/B6). Am. J. Physiol. 1991, 261, C574-C582. [CrossRef] [PubMed]

Publisher's Note: MDPI stays neutral with regard to jurisdictional claims in published maps and institutional affiliations.

(C) 2020 by the authors. Licensee MDPI, Basel, Switzerland. This article is an open access article distributed under the terms and conditions of the Creative Commons Attribution (CC BY) license (http://creativecommons.org/licenses/by/4.0/). 